\title{
Early Treatment during Primary Infection Holds the Key to a Functional Cure for HIV
}

\author{
Yu Lai \\ Department of Microbiology and Immunology, Chengdu University of Traditional Chinese Medicine, \\ Chengdu, China
}

Sir,

Combination antiretroviral therapy (cART), introduced in 1996, has significantly reduced the mortality rate and morbidity, and has improved life expectancy of HIV-infected patients [1]. However, current cART is incapable of eradicating viruses from the human body and hence does not cure the infection. Accordingly, there is a growing interest in exploring approaches which might offer long-lasting virological remission in people living with HIV. Posttreatment controllers (PTCs) have recently been defined as subjects who are initiated on cART within 10 weeks of a primary HIV infection and are able to achieve a steady state off therapy with a viral load below 400 RNA copies/ml over a period of at least 24 months [2]. They were first reported as a unique population by Hocqueloux et al. [3] in 2010. Five out of 32 patients had received antiretroviral therapy for at least 3 months. The therapy had been initiated within 3 months subsequent to the primary HIV-1 infection, but even though they later discontinued treatment they nevertheless continued to present an unusual and sustained virological control after a mean duration of 77 months [3]. Like elite controllers, these PTCs had stable CD4+ T cell counts over time with a dramatically decreased viral reservoir. Nevertheless, they did not exhibit the same protective genetic characteristics, including HLA-B*27 or
B*57 alleles or homozygous delta 32 deletion for the CCR5-encoding gene, as elite controllers did. The same group conducted a further analysis of this phenotype and offered convincing evidence that both very small HIV reservoirs and a low reservoir distribution in cell subsets with a long lifespan, induced by the early institution of cART, were crucial for the successful control of viral replication in the absence of therapy [2]. It might even be possible to realize the long-term control of infection in people with an otherwise unfavorable genetic background and, in particular, in those carrying the risk alleles HLA-B*35 and $\mathrm{B}^{*} 07$ [2]. These results suggest that an early therapeutic intervention leading to a very low viral reservoir that is unlikely to be replenished after ART suspension can be associated with an extended control of viral replication. This could provide insights which might prove to be useful in the search for a functional HIV cure.

Data emerging from clinical studies also indicate that the initiation of treatment during primary HIV-1 infection may enhance CD4+ T cell recovery and delay disease progression $[4,5]$. It is conceivable, although not tested, that there is a specific reservoir-based threshold for any given $\mathrm{HIV}$-infected individual in primary infection, below which the control of the infection could be achieved for a very long pe- riod without therapy. The early onset of cART only contributes to subsequent viral control by reducing HIV reservoirs to less than their respective thresholds in a small number of patients; this may explain the rarity of PTCs worldwide. If this assumption proves to be valid, it may pave the way for innovative strategies that limit viral reservoirs, preserve immune function, and provide a long-term or even permanent control over HIV despite the interruption of antiretroviral treatments. For example, starting short-course cART during primary infection coupled with vorinostat [6], a potent histone deacetylase inhibitor, which promotes the disruption of the latency of proviral genomes within resting $\mathrm{CD} 4+\mathrm{T}$ cells, may hold the potential to engender a desirable state of affairs where HIV-positive persons could safely stop taking antiretrovirals without experiencing viral rebound. In brief, a possible avenue towards a functional cure for HIV has been found, but pilot studies will be required to evaluate its rationality and feasibility.

\section{Disclosure Statement}

The author has no conflicts of interest to disclose.

\section{KARGER}

E-Mail karger@karger.com

www.karger.com/int (c) 2013 S. Karger AG, Base

0300-5526/14/0571-0052\$39.50/0
Yu Lai

Department of Microbiology and Immunology

Chengdu University of Traditional Chinese Medicine

37 Shi-er-qiao Road, Chengdu 610075 (China)

E-Mail archimedean@ rocketmail.com 


\section{References}

1 Antiretroviral Therapy Cohort C: Life expectancy of individuals on combination antiretroviral therapy in high-income countries: a collaborative analysis of 14 cohort studies. Lancet 2008;372:293-299.

$>2$ Saez-Cirion A, Bacchus C, Hocqueloux L, Avettand-Fenoel V, Girault I, Lecuroux C, Potard V, Versmisse P, Melard A, Prazuck T, Descours B, Guergnon J, Viard JP, Boufassa F, Lambotte O, Goujard C, Meyer L, Costagliola D, Venet A, Pancino G, Autran B, Rouzioux C, ANRS VISCONTI Study Group: Posttreatment HIV-1 controllers with a long-term virological remission after the interruption of early initiated antiretroviral therapy ANRS VISCONTI Study. PLoS Pathog 2013; 9:e1003211.
-3 Hocqueloux L, Prazuck T, Avettand-Fenoel V, Lafeuillade A, Cardon B, Viard JP, Rouzioux C: Long-term immunovirologic control following antiretroviral therapy interruption in patients treated at the time of primary HIV 1 infection. AIDS 2010;24:1598-1601.

4 Le T, Wright EJ, Smith DM, He W, Catano G, Okulicz JF, Young JA, Clark RA, Richman DD, Little SJ, Ahuja SK: Enhanced CD4+ Tcell recovery with earlier HIV-1 antiretroviral therapy. N Engl J Med 2013;368:218-230.
5 Investigators ST, Fidler S, Porter K, Ewings F, Frater J, Ramjee G, Cooper D, Rees H, Fisher M, Schechter M, Kaleebu P, Tambussi G, Kinloch S, Miro JM, Kelleher A, McClure M, Kaye S, Gabriel M, Phillips R, Weber J, Babiker A: Short-course antiretroviral therapy in primary HIV infection. N Engl J Med 2013; 368:207-217.

6 Archin NM, Liberty AL, Kashuba AD, Choudhary SK, Kuruc JD, Crooks AM, Parker DC, Anderson EM, Kearney MF, Strain MC, Richman DD, Hudgens MG, Bosch RJ, Coffin JM, Eron JJ, Hazuda DJ, Margolis DM: Administration of vorinostat disrupts HIV-1 latency in patients on antiretroviral therapy. Nature 2012;487:482-485. 